\title{
Compensation and recovery of feeding guilds in a northwest Atlantic shelf fish community
}

\author{
P. J. Auster ${ }^{1, *}$, J. S. Link ${ }^{2}$ \\ ${ }^{1}$ National Undersea Research Center and Department of Marine Sciences, University of Connecticut at Avery Point, Groton, \\ Connecticut 06340, USA \\ ${ }^{2}$ National Marine Fisheries Service, Northeast Fisheries Science Center, 166 Water St., Woods Hole, \\ Massachusetts 02543, USA
}

\begin{abstract}
Disturbance of marine ecosystems from fishing has resulted in significant shifts in the composition of fish communities. Such changes can result in shifts in dominance of functional (trophic) guilds within communities and the role that guilds play in ecosystem functioning. In particular, studies in coral reef and kelp forest fish communities have demonstrated a low level of functional redundancy, yet few studies have examined fish communities from temperate large marine ecosystems. We compared the abundance and composition of feeding guilds (i.e. planktivores, benthivores, amphipod-shrimp feeders, crabivores, echinoderm feeders, shrimp-fish feeders, and piscivores) on the continental shelf of the northeast US across 4 decades (i.e. 1970s to the present), examining changes in guild structure to determine if: (1) there have been significant changes in the abundance of functional guilds within the fish community, (2) there have been significant changes within guilds, and (3) there are commonalities in responses with studies from other habitats. We found that 5 of the 7 guilds exhibited remarkable stability in abundance over time despite extreme levels of exploitation and shifts in the abundance of individual species. We suggest there are compensatory mechanisms within those guilds that resulted in, or are an outcome of, their functional role within the shelf fish community. Comparing our results with studies in more spatially discrete habitats such as coral reefs or kelp forests suggests that erosion of functionally redundancies may be related to the resolution involved, be it spatial extent of observations, movement patterns of fishes, taxonomic precision of functional role, or variations in the diversity of species interactions within these ecosystems. Regardless, to prevent any potential for erosion of functional roles, we recommend that guild structure be considered as a unit for monitoring and resource management.
\end{abstract}

KEY WORDS: Functional redundancy - Functional diversity - Trophic guilds · Piscivores · Planktivores · Benthivores

\section{INTRODUCTION}

Disturbance by fishing activities in marine ecosystems has resulted in significant shifts in the distribution, abundance, and diversity of fish communities (e.g. Fogarty \& Murawski 1998, Auster 2002, Myers \& Worm 2003, Frank et al. 2005, Auster et al. 2006, Link 2007). Both ecological theory and empirical data demonstrate that such changes can result in long-term shifts in the dominance of species within guilds, the dominance of guilds within communities, and the roles that such guilds play in wider ecosystem functions
(Naeem 1998). From a practical perspective, changes in guild and community structure can be difficult to reverse and can alter the ecological benefits that human societies want to achieve through active management (Jackson et al. 2001, Pandolfi et al. 2003, Jackson 2008). Therefore, defining the relationships between species and their functional roles within communities is critical for understanding the dynamics of community structure as well as developing management approaches for the conservation and sustainable use of biological diversity (Micheli \& Halpern 2005, Greenstreet \& Rogers 2006). 
Functional diversity, or the diversity and relative abundance of feeding guilds within a community, is a useful measure of community state and dynamics when considering management of ecosystem properties. Micheli \& Halpern (2005) found limited redundancy of functional traits within geographically diverse marine fish communities and demonstrated reduced functional diversity within communities subject to significant levels of fishing disturbance or where habitats had been altered. However, it is of interest to note that severe changes in the functional diversity of marine communities have generally been found in habitats that have relatively discrete boundaries (e.g. coral reefs, kelp forests, semi-enclosed estuaries), where community members have limited movement rates, trophic interactions are few and strong among species or species groups, and there is little demonstrable redundancy within functional groups (Estes et al. 1989, Jackson et al. 2001, Steneck et al. 2004, Micheli \& Halpern 2005, Mumby et al. 2006). The ability to generalize the results of such studies to other fish communities (e.g. those distributed across broad areas of continental shelves, pelagic ecosystems on the high seas, and other large marine ecosystems where species exhibit significant movements between discrete habitat patches) may depend on understanding the extent to which such patterns are prevalent.

Understanding responses of exploited marine communities to human-caused disturbances is a key requirement for implementing ecosystem approaches to management (Link 2002a, Garcia et al. 2003, Garcia 2005). Marine fish communities in the northeast US continental shelf ecosystem (including Gulf of Maine and Georges Bank; hereafter the NEUS Large Marine Ecosystem [LME]) have been subjected to high levels of exploitation that escalated in the late 1950s and early 1960s and continued until the early 1990s when populations of economically important species reached historic lows (Fogarty \& Murawski 1998, Link et al. 2002). During this same time period the level and distribution of fishing effort was extensive (Auster et al. 1996, Murawski et al. 2005), with resultant and variable alterations to seafloor habitats (e.g. Auster et al. 1996, Auster \& Langton 1999, Lindholm et al. 2004, Collie et al. 2005). There also have been notable changes in broader systemic metrics, such as changes in the size classes and dominance of zooplankton and fishes, in part due to a warming trend over the past half century (Link et al. 2002, Pershing et al. 2005, Greene \& Pershing 2007, Kane 2007, Collie et al. 2008). Despite such changes over time, there has yet to be a comprehensive assessment of the potential shifts or dynamics in functional diversity of the NEUS continental shelf fish community (c.f. Link 2007, Steele et al. 2007).
A feeding guild-based approach is one way in which we can evaluate how much the combined effects of exploitation, habitat, climate, and ecosystem change have affected functional diversity of the fish community. Previous studies have demonstrated that the shelf fish community in the NEUS LME can be partitioned into 7 distinct feeding guilds (sensu Garrison \& Link 2000a,b): planktivores, benthivores, amphipodshrimp feeders, crabivores, echinoderm feeders, shrimp-fish feeders, and piscivores. In the present study we quantified patterns in the abundance and composition of feeding guilds of fishes across 4 decades (i.e. 1970 s to the present). We looked at changes within and among guild structure to ascertain if there have been significant changes in the functional role of guilds within the fish community over time as well as commonalities in responses to changes observed in studies from other ecosystems.

\section{MATERIALS AND METHODS}

Data collection. The standard Northeast Fisheries Science Center (NEFSC) bottom trawl survey program has been executed annually since 1963 (Grosslein 1969, Azarovitz 1981, NEFC 1988). These multi-species surveys were designed to monitor trends in abundance and distribution and to provide samples to study the ecology of the large number of fish and invertebrate species inhabiting the region. During these surveys, food habits data are also collected from a variety of species. Although these broad-scale trawl surveys cover continental shelf waters from Cape Hatteras to Nova Scotia (approximately $290000 \mathrm{~km}^{2}$ ), we focused our analysis on the Gulf of Maine and Georges Bank regions of the NEUS LME (Fig. 1). Each station was sampled using a No. 36 Yankee (or similar) bottom trawl deployed for $30 \mathrm{~min}$, towed at a speed of $6.5 \mathrm{~km}$ $\mathrm{h}^{-1}$. Tows were executed at 350 to 400 sampling stations using a stratified-random sampling design

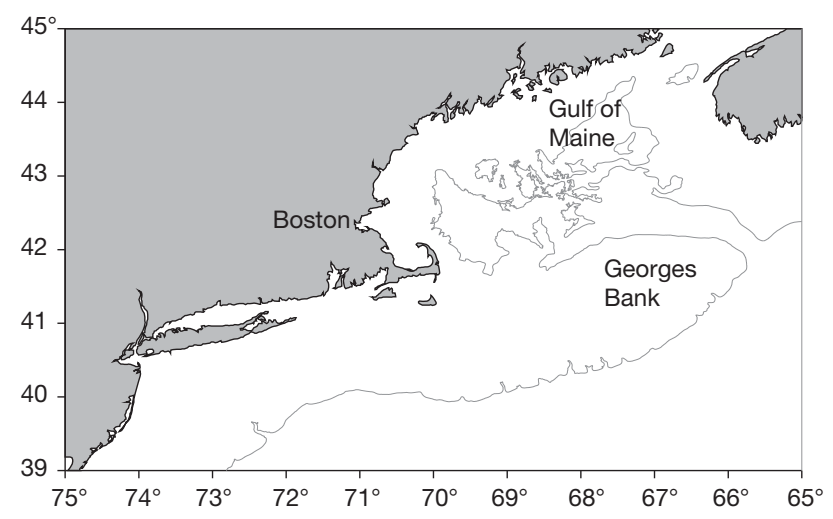

Fig. 1. Gulf of Maine and Georges Bank region (200 m isobath defines shelf margin and deep basins within the Gulf) 
(NEFC 1988). Within each stratum, 2' latitude by $2.5^{\prime}$ longitude rectangular sampling units were randomly selected in proportion to the strata area (approximately 1 station per 200 square nautical miles or per $690 \mathrm{~km}^{2}$ ). The surveys were conducted in depths of 27 to $366 \mathrm{~m}$; however, greater depths were occasionally sampled in the deep canyons along the continental shelf break.
Individuals in the catch were sorted to species, weighed in aggregate (to the nearest $0.1 \mathrm{~kg}$ ) and measured (to the nearest $\mathrm{cm}$ ), and sex and maturity were determined. Subsamples of key species were eviscerated for feeding ecology studies with weight and size measurements collected for each fish. These data on the distribution, abundance, and ecology of northwest

Table 1. List of species and trophic guild membership based on size class (cm). Ontogentic shifts in guild membership and associated size classes are based on Garrison \& Link (2000a). Pl: planktivore; A-S: amphipod-shrimp feeder; Cr: crabivore S-F: shrimp-fish feeder; Be: benthivore; Ec: echinoderm feeder; Pi: piscivore

\begin{tabular}{|c|c|c|c|c|c|c|c|}
\hline \multirow{2}{*}{$\begin{array}{l}\text { Common name } \\
\text { Sandlance }\end{array}$} & \multicolumn{2}{|l|}{ Scientific name } & \multicolumn{5}{|c|}{ Guild(s) and size class $(\mathrm{cm})$} \\
\hline & Ammodytes sp. & $\mathrm{Pl}$ & All & & & & \\
\hline Atlantic herring & Clupea harengus & $\mathrm{Pl}$ & All & & & & \\
\hline Butterfish & Peprilus tricanthus & $\mathrm{Pl}$ & All & & & & \\
\hline Atlantic mackerel & Scomber scombrus & $\mathrm{Pl}$ & All & & & & \\
\hline Alewife & Alosa pseudoharengus & $\mathrm{Pl}$ & All & & & & \\
\hline Spiny dogfish & Squalus acanthias & $\mathrm{Pl}$ & $10-60$ & $\mathrm{Pi}$ & $>60$ & & \\
\hline Shortfin squid & Illex illecebrosus & $\mathrm{Pl}$ & All & & & & \\
\hline Longfin squid & Loligo pealeii & $\mathrm{Pl}$ & All & & & & \\
\hline American shad & Alosa sapidissima & $\mathrm{Pl}$ & All & & & & \\
\hline Hickory shad & Also mediocris & $\mathrm{Pl}$ & All & & & & \\
\hline Fawn cusk-eel & Lepophidium profundorum & A-S & All & & & & \\
\hline Longhorn sculpin & Myохосерhalus octodecemspinosus & A-S & All & & & & \\
\hline Windowpane & Scophthalmus aquosus & A-S & All & & & & \\
\hline Atlantic cod & Gadus morhua & A-S & $10-50$ & $\mathrm{Pi}$ & $>50$ & & \\
\hline Winter skate & Leucoraja ocellata & A-S & $10-60$ & $\mathrm{Pi}$ & $>60$ & & \\
\hline Little skate & Leucoraja erinacea & A-S & $10-60$ & S-F & $>60$ & & \\
\hline Red hake & Urophycis chuss & A-S & $10-40$ & S-F & $>40$ & & \\
\hline Spotted hake & Urophycis regia & A-S & $10-20$ & $\mathrm{Pi}$ & $>20$ & & \\
\hline White hake & Urophycis tenuis & A-S & $10-20$ & S-F & $21-40$ & $\mathrm{Pi}$ & $>40$ \\
\hline Fourspot flounder & Paralichthys oblongus & A-S & $10-20$ & $\mathrm{Pi}$ & $>20$ & & \\
\hline Yellowtail flounder & Limanda ferruginea & A-S & $10-20$ & $\mathrm{Be}$ & $>20$ & & \\
\hline Northern sea robin & Prionotus carolinus & A-S & All & & & & \\
\hline American plaice & Hippoglossoides platessoides & A-S & $10-20$ & Ec & $>20$ & & \\
\hline Clearnose skate & Raja eglanteria & A-S & $10-30$ & $\mathrm{Cr}$ & $31-60$ & S-F & $>60$ \\
\hline Smooth dogfish & Mustelus canis & $\mathrm{Cr}$ & All & & & & \\
\hline Black sea bass & Centropristis striata & $\mathrm{Cr}$ & All & & & & \\
\hline Pollock & Pollachius virens & S-F & All & & & & \\
\hline Silver hake & Merluccius bilinearis & S-F & $10-40$ & $\mathrm{Pi}$ & $>40$ & & \\
\hline Acadian redfish & Sebastes fasciatus & S-F & All & & & & \\
\hline Smooth skate & Malacoraja senta & S-F & All & & & & \\
\hline Blackbelly rosefish & Helicolenus dactylopterus & S-F & All & & & & \\
\hline Cusk & Brosme brosme & S-F & All & & & & \\
\hline Haddock & Melanogrammus aeglefinus & $\mathrm{Be}$ & $10-20$ & Ec & $>20$ & & \\
\hline Thorny skate & Amblyraja radiata & $\mathrm{Be}$ & $10-60$ & $\mathrm{Pi}$ & $>60$ & & \\
\hline Winter flounder & Pseudopleuronectes americanus & $\mathrm{Be}$ & All & & & & \\
\hline Gulf Stream flounder & Citharichthys arctifrons & $\mathrm{Be}$ & All & & & & \\
\hline Witch flounder & Glyptocephalus cynoglossus & $\mathrm{Be}$ & All & & & & \\
\hline Scup & Stenotomus chrysops & $\mathrm{Be}$ & All & & & & \\
\hline Atlantic croaker & Micropogonias undulatus & $\mathrm{Be}$ & All & & & & \\
\hline Cunner & Tautogolabrus adspersus & $\mathrm{Be}$ & All & & & & \\
\hline Tautog & Tautoga onitis & $\mathrm{Be}$ & All & & & & \\
\hline Ocean pout & Macrozoarces americanus & Ec & All & & & & \\
\hline Sea raven & Hemitripterus americanus & $\mathrm{Pi}$ & All & & & & \\
\hline Goosefish & Lophius americanus & $\mathrm{Pi}$ & All & & & & \\
\hline Bluefish & Pomatomus saltatrix & $\mathrm{Pi}$ & All & & & & \\
\hline Weakfish & Cynoscion regalis & $\mathrm{Pi}$ & All & & & & \\
\hline Summer flounder & Paralichthys dentatus & $\mathrm{Pi}$ & All & & & & \\
\hline Atlantic halibut & Hippoglossus hippoglossus & $\mathrm{Pi}$ & All & & & & \\
\hline
\end{tabular}


Atlantic fish and invertebrates have been routinely collected in all 4 seasons, but the major focus has been in spring (March to May) and fall (September to November), with winter and summer surveyed more sporadically (Grosslein 1969, Azarovitz 1981, NEFC 1988). Azarovitz (1981) and NEFC (1988) provide a more detailed description of the survey program. Further details of the food habits sampling and data are given in Link \& Almeida (2000), data from which were used to determination guild membership.

Analysis. We assigned a suite of 48 species to 7 distinct functional trophic groups following the guild delineation of Garrison \& Link (2000a,b) (Table 1). We then calculated a stratified mean average abundance for each species (or species-size combination) individually and collectively for each guild. These were averaged across seasons and were executed for a 4 yr range during the early part of each decadal period, starting at 1970 (i.e. 1970 to 1973), 1980, 1990, and 2000. We present the mean abundance (no. tow $^{-1}$ ) for each guild and relative proportion within each guild. We made the a priori choice of $4 \mathrm{yr}$ time periods in each decade to emphasize any potential contrasts and changes over the $40+\mathrm{yr}$ of the data series in a discrete manner (i.e. rather than arbitrarily extract segments in a post hoc manner for illustrative purposes from an analysis of the entire time series). Further, we made the a priori decision to address changes in patterns of numerical abundance rather than biomass. From a population and community perspective, showing change in numerical abundance within a guild, although related closely to biomass, is in keeping with both prior studies of functional diversity and the emphasis on total number of functional parts (regardless of how much an individual part weighs).

A 1-way ANOVA was used to determine if there were significant changes in the distribution of trophic group abundances across eras with years as replicates within each era. We conducted Tukey's HSD tests to ascertain differences among the means in each era for each guild where there were significant differences. Two-way ANOVAs were used to test for differences between eras in the proportional composition of species within each guild. Proportions were arcsin square root-transformed (Zar 1999).

\section{RESULTS}

\section{Between guilds}

We found 2 guilds with large differences in abundance over time (Fig. 2). Both planktivores and the shrimp-fish guilds were significantly different across

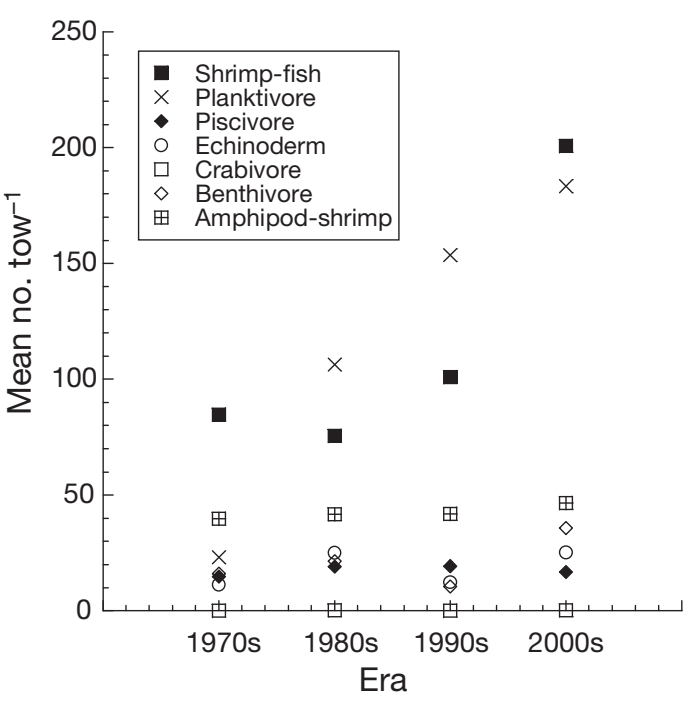

Fig. 2. Abundance of trophic guilds across eras

eras (ANOVA, $F_{3,12}=37.05$ and 68, respectively), with the highest abundance for each guild of approximately 200 individuals per sample tow in the 2000s era. For planktivores, results of Tukey's pair-wise comparisons demonstrated significant differences $(p<0.05)$ between each era (i.e. 1970 s < 1980s < 1990s < 2000s). Unlike the planktivore guild, the shrimp-fish guild did not exhibit statistically distinct differences throughout the time series (i.e. $1970 \mathrm{~s}=1980 \mathrm{~s}=1990 \mathrm{~s}<2000 \mathrm{~s}$ ) except for the last era. These 2 guilds were consistently the most abundant in this fish community.

The remaining guilds exhibited a relatively stable abundance over time (Fig. 2). Two guilds (benthivores and echinoderm feeders) did exhibit small but significant changes in abundance across eras (ANOVA, $F_{3,12}=5.76$ and 3.76, p = 0.011 and 0.041, respectively). Although statistically different, the relative magnitude of the differences was minor (i.e. less than $\sim 15$ to 20 ind. tow ${ }^{-1}$ ). For the benthivores, results of Tukey's comparisons demonstrated that only the 2000-2003 era was statistically different $(p<0.05)$ than all of the earlier eras. There were no significant differences derived from Tukey's comparisons of echinoderm feeders across eras despite the significant results of the ANOVA. This result can be attributed to the wide variation in the data from a limited number of species. Both guilds exhibited their highest level of abundance in the 2000s era followed closely by the 1980s. The 3 remaining guilds showed no significant differences across the 4 decades. The piscivores were relatively consistent with 15 to 20 ind. tow $^{-1}\left(F_{3,12}=1.20, \mathrm{p}=0.353\right)$, the amphipod-shrimp feeders with 40 to 45 ind. tow $^{-1}\left(F_{3,12}=1.59, \mathrm{p}=\right.$ 0.243 ), and the crabivores with 0.003 to 0.2 ind. tow ${ }^{-1}$ $\left(F_{3,12}=0.90, \mathrm{p}=0.470\right)$. 


\section{Within guilds}

The representation of species abundances within guilds shifted dramatically over time and not in synchrony with guild abundance. Two-way ANOVAs comparing the proportion of species within each guild across time produced significant results for 6 of 7 guilds based on changes in the proportions of individual species and the interaction between species proportions and era $\left(\mathrm{p}_{\text {crit }}<0.05\right.$; Table 2$)$. Conversely, the era term alone was not significant (Table 2). The only guild for which no significant differences were found was crabivores, which were represented by only 3 species.

The relative proportion of herring in the planktivore guild increased greatly after the 1970s and 1980s as did Atlantic mackerel (Fig. 3a). The most notable species shift in this guild was the high level of abundance of sand lance in the 1980s and its greatly reduced abundance in relation to other species in all other eras. Long-finned squid also changed in abundance over time, with levels in the 2000-2003 era approaching the highest levels of abundance observed in the 1970s. The shrimp-fish guild (Fig. 3b) exhibited distinct shifts in abundance between silver hake and Acadian redfish, particularly at higher levels of guild abundance in the 1980s and 1990s. Other species in this guild exhibited compensatory dynamics but constituted only minor fractions of the total guild abundance.

Dynamics of species abundances in the benthivore and echinoderm guilds (Fig. 3c,d, respectively) were primarily due to changes in haddock abundance for given size classes (i.e. small haddock as benthivores and medium, large, and extra-large haddock as echinoderm feeders). Both guilds contained a higher amount of haddock in the 2000-2003 era. Although the relative proportion and absolute abundance of winter flounder and yellowtail flounder changed in the benthivore guild, most changes in proportions were reflective of changes in haddock abundance. The same is true for ocean pout and American plaice in the echinoderm guild.

Despite the overall stability in abundance of the remaining 3 guilds (Fig. 3e,f,g), their composition also exhibited notable changes. The shifts in component species in the piscivore guild included a decline in Atlantic cod over time, an increase in fourspot flounder, and an increase then subsequent decline in spiny dogfish. The relative abundances of the remaining species in this guild responded proportionally to changes primarily in Atlantic cod and spiny dogfish abundance. The amphipod-shrimp-feeding guild exhibited an increase in red hake over time. Little skate was most abundant in the 1980s and then declined. Longhorn sculpin were least abundant in the 1980s and have since increased in relative abundance, almost to proportions observed in the 1970s. Finally, the crabivore guild exhibited a trade-off between smooth dogfish and black seabass: smooth dogfish were most abundant in the 1970s and 1990s; conversely, black seabass had the highest proportional abundance in the 1980s and 2000s.
Table 2. Results of 2-way ANOVA comparing guild structure between eras. ${ }^{*}$ : significant at $\mathrm{p}<0.05$

\begin{tabular}{|llrrc|}
\hline \multirow{2}{*}{ Trophic guild } & Source & df & $F$ & $\mathrm{p}$ \\
\hline Amphipod-shrimp & Species proportion & 11 & 153.61 & $<0.0001^{*}$ \\
& Era & 2 & 0.18 & 0.9070 \\
& Proportion $\times$ Era & 32 & 2.70 & $<0.0001^{*}$ \\
& Species proportion & 9 & 29.26 & $<0.0001^{*}$ \\
& Era & 3 & 0.74 & 0.5333 \\
Crabivore & Proportion $\times$ Era & 25 & 2.85 & $0.0001^{*}$ \\
& Species proportion & 2 & 0.61 & 0.5549 \\
Echinoderm & 3 & 0.14 & 0.9326 \\
& Era & 3 & 0.70 & 0.5642 \\
& Proportion $\times$ Era & 2 & 68.30 & $<0.0001^{*}$ \\
& Species proportion & 3 & 0.06 & $0.9799^{*}$ \\
& Era & 6 & 10.24 & $<0.0001^{*}$ \\
& Proportion $\times$ Era & 12 & 182.58 & $<0.0001^{*}$ \\
Planktivore & Species proportion & 3 & 1.27 & 0.2857 \\
& Era & 36 & 11.58 & $<0.0001^{*}$ \\
& Proportion $\times$ Era & 9 & 39.69 & $<0.0001^{*}$ \\
Shrimp-fish & Species proportion & 3 & 0.15 & 0.9325 \\
& Era & 24 & 8.43 & $<0.0001^{*}$ \\
& Proportion $\times$ Era & 8 & 288.23 & $<0.0001^{*}$ \\
& Species proportion & 3 & 2.19 & 0.0939 \\
& Era & 23 & 14.25 & $<0.0001^{*}$ \\
& Proportion $\times$ Era & & \\
\hline
\end{tabular}

\section{DISCUSSION}

Overall our results demonstrate that 5 of the 7 guilds exhibited remarkable stability in abundance over time despite extreme levels of exploitation, major ecosystem changes, and highly notable shifts in the abundance of individual species. We suggest that there are compensatory mechanisms within those guilds that resulted in, or are an outcome of, their functional role within the shelf fish community. While other studies have demonstrated severe declines in the abundance of functional groups in the face of exploitation, with cascading effects across trophic levels (e.g. Hughes 1994, Steneck et al. 2004), our results suggest an alternative outcome. There are several potential reasons for such a pattern: (1) a high level of functional 
(a) Planktivore guild

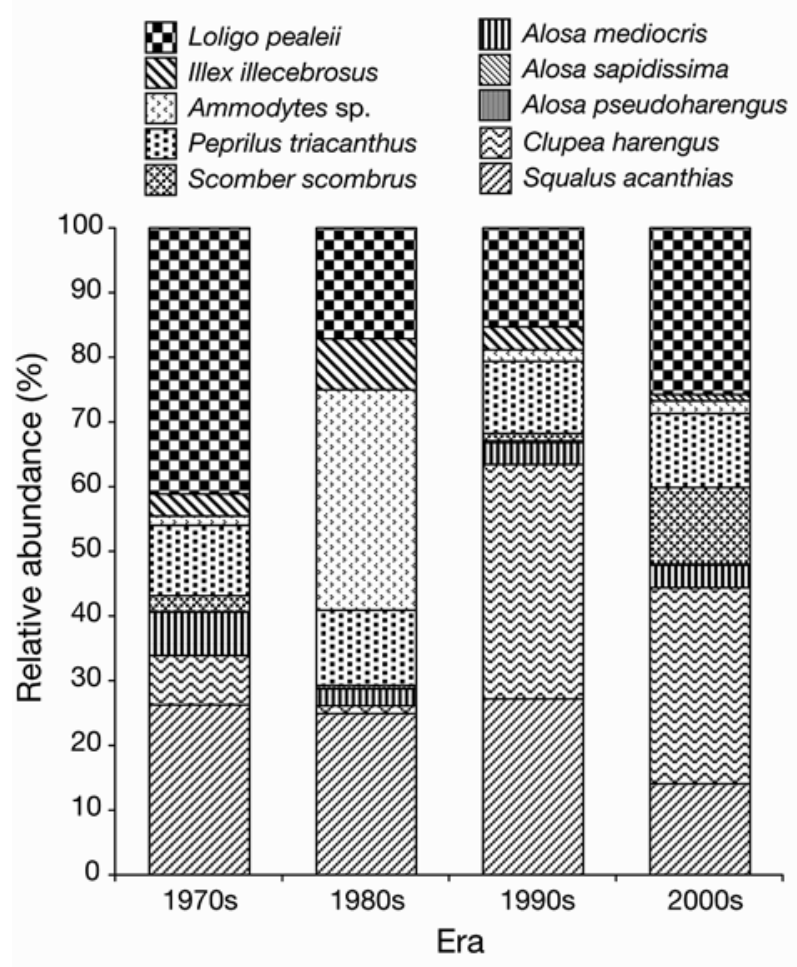

(b) Shrimp-fish-feeding guild

$\mathbf{W}$ Helicolenus dactylopterus

$\begin{array}{ll}\text { Sebastes fasciatus } & \text { Pollachius virens } \\ \text { Burosme brosme } & \text { Merluccius bilinearis } \\ \text { U. } & \text { Malacoraja senta } \\ \text { Urophycis tenuis } & \text { Leucoraja erinacea }\end{array}$

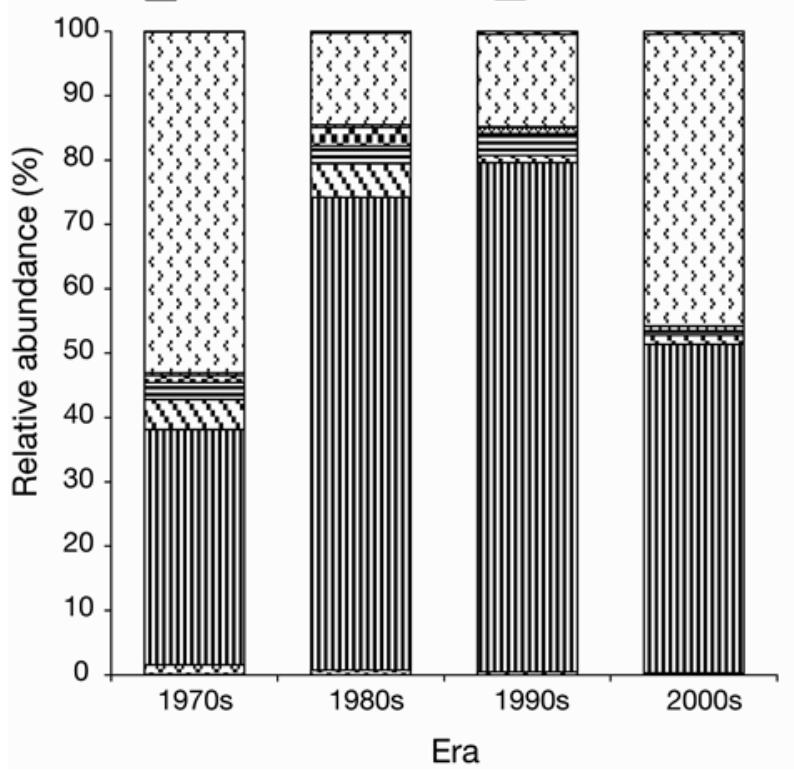

(c) Benthivore guild

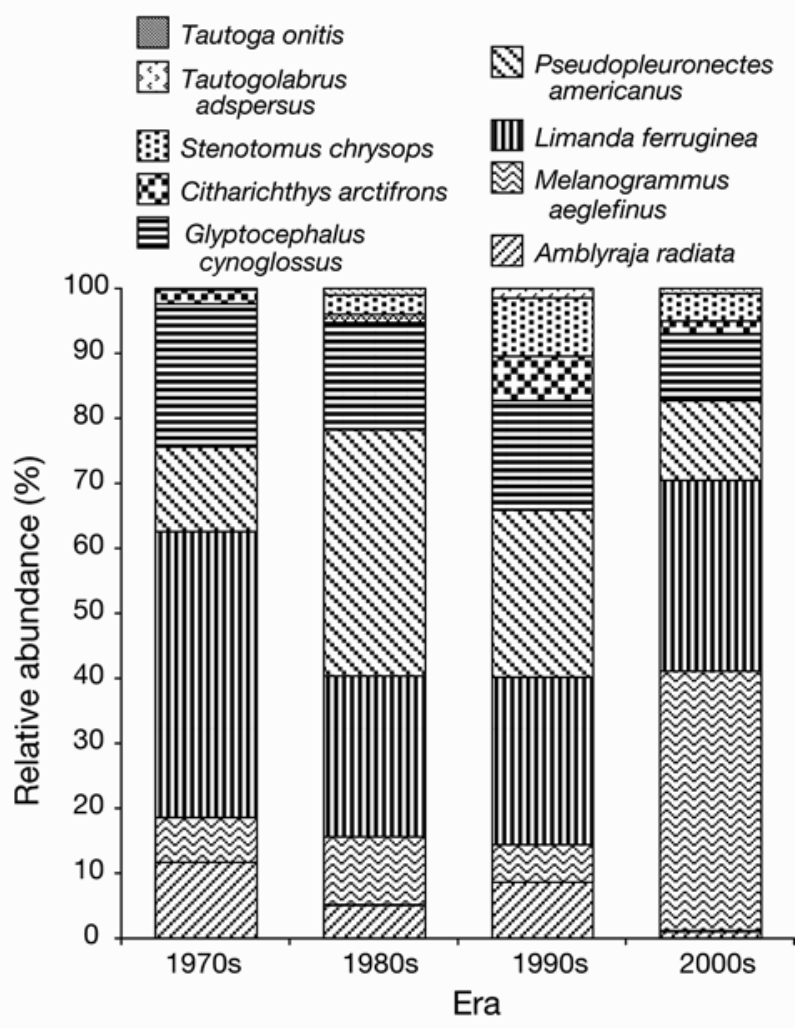

(d) Echinoderm-feeding guild

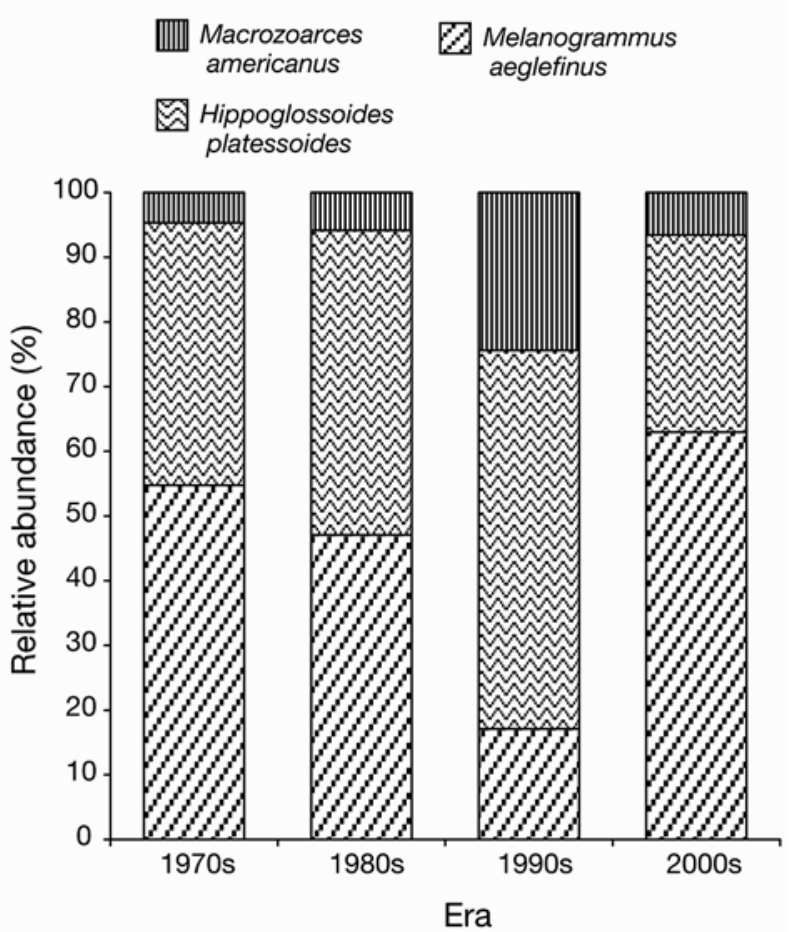

Fig. 3 (this and facing page). Proportional composition of species in the 7 guilds across the 4 eras addressed in the present study (1970s to 2000s). Diet characteristics are described in Garrison \& Link (2000a) 
(e) Piscivore guild

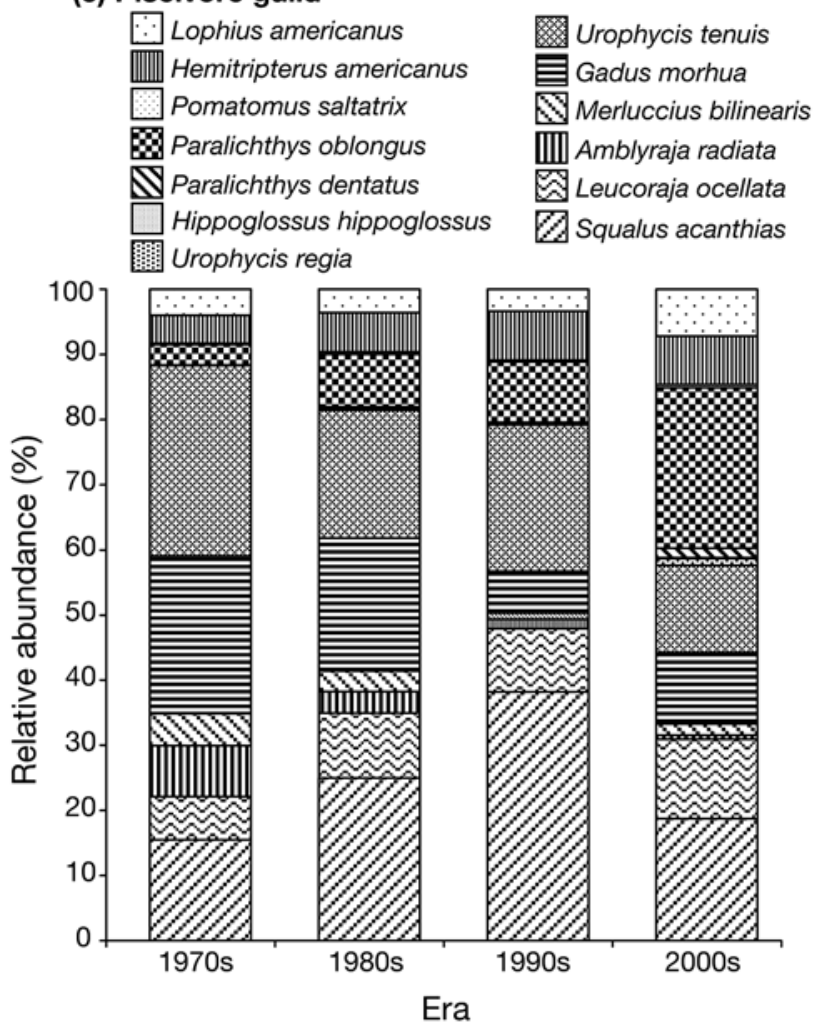

(f) Amphipod-shrimp feeding guild

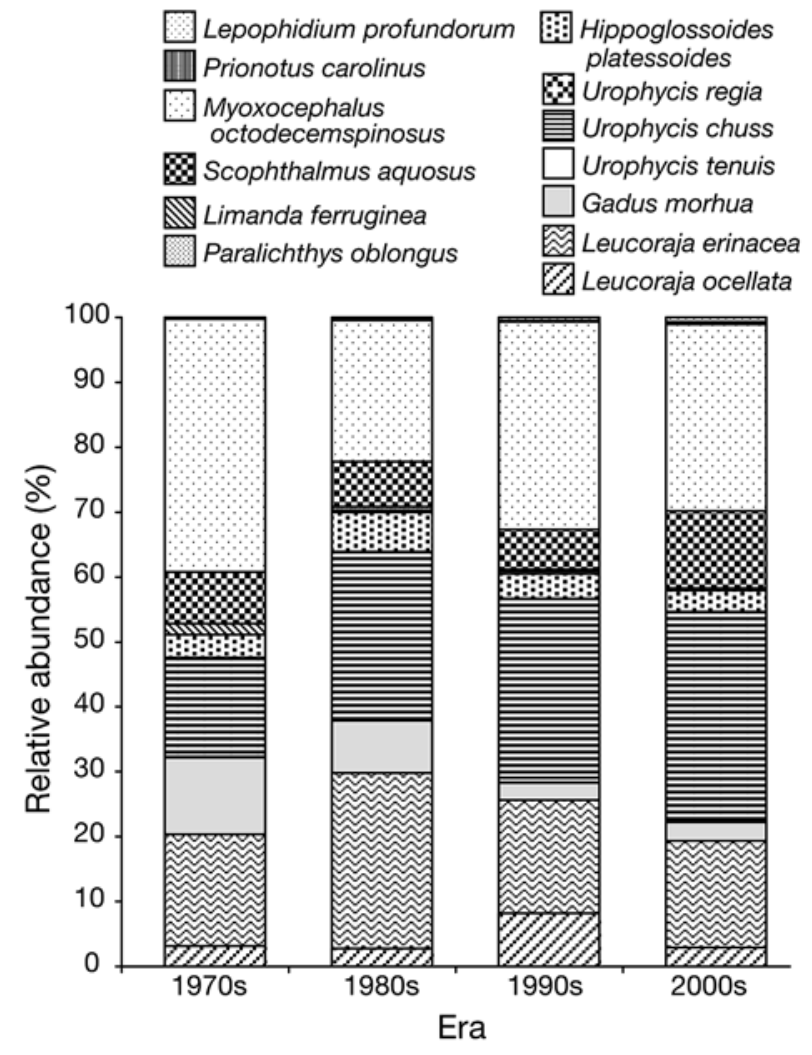

\section{(g) Crabivore guild}

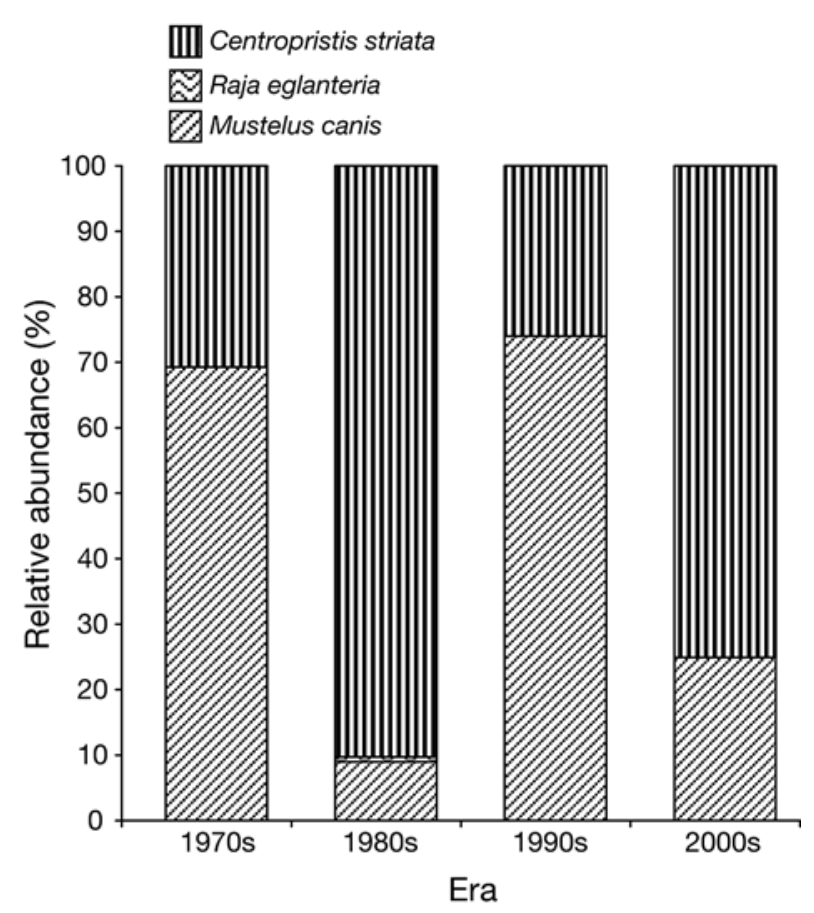

redundancy and spatial overlap in the distribution of guild members where the role of a species in decline is replaced by others with concomitant increases in abundance; (2) the disparities in spatial scale of studies contrasting systems like reefs and kelp forests with shelf-wide systems masks large-scale patterns in the former or small-scale patterns in the latter such that there may be similarities if spatial scales of observation are matched; (3) differences in the taxonomic resolution of guild membership across studies; or (4) differences in species interactions between discrete habitats (or other diversity-related processes that vary with the spatial scale of observation) that contribute to the disparate outcomes.

While some studies have found low levels of redundancy of functional groups within communities, none save the present study have found a high degree of functional redundancy. Garrison \& Link (2000) found a high degree of dietary overlap within guilds (i.e. $\sim 0.50$ ) but a relatively low degree of overlap between guilds (mean dietary overlap of 0.23 ) within the NEUS LME region. They attributed this pattern to the large spatial extent of the study area, where samples were collected across multiple habitats and the number of potential predator-prey species interactions was higher, thereby reducing overlap within guilds (while identifying distinctly different guilds based on broad 
taxonomic differences in prey). The low levels of redundancy in other studies could, in part, be due to the lack of high resolution food habits studies to elucidate ontogenetic changes in trophic role where a species is assigned to a single guild regardless of size (Link et al. 2005, Essington et al. 2006), despite the commonality of size-based shifts in diet (Ross 1986, Garrison \& Link 2000a). For example, the trophic role of coral reef fishes in the Caribbean Sea is often assigned from limited historic studies of food habits in specific locations (e.g. Randall 1967, Auster et al. 2005, Mumby et al. 2006, Newman et al. 2006). As the taxonomic resolution of the functional role of each species is increased, we may find there is more functional redundancy than has been previously suspected. Expanding these types of studies across spatial and temporal scales may also alter our perception of functional diversity and thus systemic resiliency.

The spatial boundary of the present study was the $200 \mathrm{~m}$ isobath of the NEUS continental shelf, defining essentially a large fraction of the entire northeast continental shelf, not a particular habitat or landscape. However, we do not assume that interactions within and between guilds (that is, their functional roles) are evenly distributed in space and time. Previous studies have demonstrated non-random distributions of fishes within the region (e.g. Auster et al. 2006, Methratta \& Link 2006) and community boundaries have been delimited at smaller spatial scales in this LME (Overholtz \& Tyler 1985, Gabriel 1992, Langton et al. 1995, Auster 2002). Such community boundaries do not necessarily imply that individual fish, and hence species interactions, are bounded to those locations, but only that patterns of species composition are consistent over time in spatially limited areas. An analysis of the spatial and temporal patterns of functional groups across the region remains to be conducted.

However, at the spatial scale of landscapes (i.e. banks, basins) and the habitats nested within (e.g. gravel pavement, boulder reef, sand wave field) we can assume a level of residency for some species within guilds (e.g. Auster \& Lindholm 2005, Lindholm et al. 2007). If immigration is not the major mode of recovery at ecologically relevant time scales, fishinginduced mortality could have significant effects on the strength of ecological interactions at local spatial scales. In contrast, studies focused on coral reefs and kelp forests have the inherent assumption of non-leakiness (i.e. higher residency) in terms of the consistency of the presence and abundance of species (or some mix of species within guilds) and their ability to carry out their functional role within these discrete habitats (e.g. Steneck et al. 2004, Micheli \& Halpern 2005). Such patterns have not been tested explicitly in any of these cases and there has been no evaluation of the role of transient guild members entering and leaving particular habitats. We note that the degree of leakiness implies the presence of the mix of species that perform guild roles within habitats (e.g. presence that controls abundance of seasonally recurring recruits). However, the spatial and temporal extent of species interactions necessary to maintain functional roles within habitats remains unknown.

The present study was not designed to develop a mechanistic understanding of changes in functional diversity over time but to identify dynamics within and between guilds of this cold, temperate fish community. The complexity of trophic interactions (Link 2002b), non-random patterns of exploitation (Murawski et al. 2005), population responses to changes in habitat (e.g. Lindholm et al. 2001, Auster et al. 2003), and interactions with large-scale climate effects (e.g. Drinkwater 2005, Hare \& Able 2007) yield many multiple, and not necessarily mutually exclusive, hypotheses to explain patterns in the abundance of functional groups and their component parts. The interactions between these factors, as well as the spatial and temporal scales at which manipulations must be made in order to understand the mechanisms driving community dynamics, require design and implementation of experiments in collaboration with fisheries management (i.e. adaptive management; Walters 1986).

The results of the present study have important implications for conservation and management of marine biological diversity. First, that there is high functional redundancy within guilds and a form of compensatory response to exploitation implies a degree of resiliency able to accommodate (potential or realized) resource management mistakes, at least from the standpoint of maintaining ecosystem function. It appears that, at least in this fish community, the functional redundancies of most guilds have been maintained despite a history of notable exploitation. The second main implication is that setting allowable catch levels for functional guilds rather than single species can focus management on ecological roles and ultimately may yield greater stability of catches (Mangel \& Levin 2005, Mueter \& Megrey 2006). Of the 7 guilds we examined, only 2 showed notable changes (both increases), and that was after a significant reduction of fishing pressure on both guilds, prior to the time series used in our analysis, due to both economic priorities and management actions (Fogarty \& Murawski 1998). Considering management from a functional role perspective not only will help to avoid potential erosion of ecological roles (sensu Micheli \& Halpern 2005), but may be more economically stable for fishers (Edwards et al. 2004). We do note the need to continue to elucidate details and dynamics of responses of species within guilds in this and related ecosystems; in partic- 
ular, understanding the effects of sequential depletion of species within guilds merits further exploration.

Here we have demonstrated that there is a level of functional redundancy in the NEUS LME fish community which has responded to most levels of fishing effort resulting in the maintenance of relative proportions of species' respective ecological roles. This differs from other studies likely due to the various factors as noted above (i.e. taxonomic resolution of functional roles, spatial extent, movement rates of fishes). However, even in this system with high functional redundancy, we have seen significant changes in guild abundance of 2 groups (e.g. planktivores, shrimp-fish feeders). It is clear that a portion of the fish community had to have been impacted significantly for such changes in species abundances; it is also clear that this impact must have been even more significant to have changed the status of entire guilds, particularly given the stability of others. Yet even with the large impacts suggested by the changes to some of the guilds in this ecosystem, there hasn't been an overall deterioration of functional roles of fish in this ecosystem as compared to other systems (e.g. Estes et al. 1989, Pandolfi et al. 2003, Mumby et al. 2006). To mitigate against future deleterious changes, a guild-level perspective in a resource management context would be advisable (e.g. Mangel \& Levin 2005, Link 2007). Doing so would be a practical implementation of ecosystem-based management (Link 2002a, Garcia et al. 2003, Garcia 2005) and may help to avoid the potential for any future erosion of functional roles and the ecological benefits we derive from this important ecosystem.

Acknowledgements. We thank the personnel who have designed, implemented, and conducted the bottom trawl surveys upon which this analysis is based. We also thank 2 anonymous reviewers for constructive comments on prior versions of this manuscript. P.J.A. was supported by the Census of Marine Life Gulf of Maine Program and NOAA's National Undersea Research Program. The opinions expressed herein are those of the authors and do not necessarily reflect the opinions of NOAA, the Census of Marine Life, or its subagencies.

\section{LITERATURE CITED}

Auster PJ (2002) Representation of biological diversity of the Gulf of Maine region at Stellwagen Bank National Marine Sanctuary (northwest Atlantic): patterns of fish diversity and assemblage composition. In: Bondrup-Nielson $\mathrm{S}$, Herman T, Munro NWP, Nelson G, Willison JHM (eds) Managing protected areas in a changing world. Science and Management of Protected Areas Association, Wolfville, NS, p 1096-1125

Auster PJ, Langton RW (1999) The effects of fishing on fish habitat. Am Fish Soc Symp 22:150-187

Auster PJ, Lindholm J (2005) The ecology of fishes on deep boulder reefs in the western Gulf of Maine. In: Godfrey J,
Shumway S (eds) Proc Am Acad Underwater Sci. Connecticut Sea Grant, Groton, CT, p 91-109

Auster PJ, Malatesta RJ, Langton RW, Watling L and others (1996) The impacts of mobile fishing gear on seafloor habitats in the Gulf of Maine (northwest Atlantic): implications for conservation of fish populations. Rev Fish Sci 4: 185-202

> Auster PJ, Lindholm J, Valentine PC (2003) Variation in habitat use by juvenile Acadian redfish, Sebastes fasciatus. Environ Biol Fishes 68:381-389

Auster PJ, Semmens B, Barber K (2005) Pattern in the cooccurrences of fishes inhabiting the coral reefs of Bonaire, Netherlands Antilles. Environ Biol Fishes 74:187-194

Auster PJ, Clark R, Reed RES (2006) Marine fishes. In: Battista T, Clark R, Pittman S (eds) An ecological characterization of the Stellwagen Bank National Marine Sanctuary Region: oceanographic, biogeographic, and contaminants assessment. NOAA Tech Memo NCCOS 45:89-229

Azarovitz TR (1981) A brief historical review of the Woods Hole Laboratory trawl survey time series. Can Spec Publ Fish Aquat Sci 58:62-67

Collie JS, Hermsen JM, Valentine PC, Almeida FP (2005) Effects of fishing on gravel habitats: assessment and recovery of benthic megafauna on Georges Bank. Am Fish Soc Symp 41:325-343

Collie JS, Wood AD, Jeffries HP (2008) Long-term shifts in the species composition of a coastal fish community. Can J Fish Aquat Sci 65:1352-1365

Drinkwater KF (2005) The response of Atlantic cod (Gadus morhua) to future climate change. ICES J Mar Sci 62: 1327-1337

Edwards SF, Link JS, Rountree BP (2004) Portfolio management of wild fish stocks. Ecol Econ 49:317-329

Essington TE, Beaudreau AH, Wiedenmann J (2006) Fishing through marine food webs. Proc Natl Acad Sci USA 103:3171-3175

> Estes JA, Duggins DO, Rathbun GB (1989) The ecology of extinctions in kelp forest communities. Conserv Biol 3:252-264

Fogarty MJ, Murawski SA (1998) Large-scale disturbance and the structure of marine systems: fishery impacts on Georges Bank. Ecol Appl 8:S6-S22

Frank KT, Petrie B, Choi JS, Leggett WC (2005) Trophic cascades in a formerly cod-dominated ecosystem. Science 308:1621-1623

Gabriel W (1992) Persistence of demersal fish assemblages between Cape Hatteras and Nova Scotia, Northwest Atlantic. J Northwest Atl Fish Sci 14:29-46

Garcia SM (2005) Fishery science and decision-making: dire straights to sustainability. Bull Mar Sci 76:171-196

Garcia SM, Zerbi A, Aliaume C, Do Chi T, Lasserre G (2003) The ecosystem approach to fisheries: issues, terminology, principles, institutional foundations, implementation and outlook. FAO Technical Paper 443, FAO, Rome

> Garrison LP, Link J (2000a) Dietary guild structure of the fish community in the northeast United States continental shelf ecosystem. Mar Ecol Prog Ser 202:231-240

> Garrison LP, Link JS (2000b) Fishing effects on spatial distribution and trophic guild structure of the fish community in the Georges Bank region. ICES J Mar Sci 57:723-730

Greene CH, Pershing AJ (2007) Climate drives sea change. Science 315:1084-1085

- Greenstreet SPR, Rogers SI (2006) Indicators of the health of the North Sea fish community: identifying reference levels for an ecosystem approach to management. ICES J Mar Sci 63:573-593

Grosslein MD (1969) Groundfish survey program of the BCF Woods Hole. Commer Fish Rev 31:22-30 
Hare JA, Able KW (2007) Mechanistic links between climate and fisheries along the east coast of the United States: explaining population outbursts of Atlantic croaker (Micropogonias undulatus). Fish Oceanogr 16:31-45

Hughes TP (1994) Catastrophes, phase shifts, and large-scale degradation of a Caribbean coral reef. Science 265: $1547-1551$

Jackson JBC (2008) Ecological extinction and evolution in the brave new ocean. Proc Natl Acad Sci USA 105: 11458-11465

Jackson JBC, Kirby MX, Berger WH, Bjorndal KA and others (2001) Historical overfishing and the recent collapse of coastal ecosystems. Science 293:629-638

Kane J (2007) Zooplankton abundance trends on Georges Bank, 1977-2004. ICES J Mar Sci 64:909-919

Langton RW, Auster PJ, Schneider DC (1995) A spatial and temporal perspective on research and management of groundfish in the northwest Atlantic. Rev Fish Sci 3: 201-229

Lindholm JB, Auster PJ, Ruth M, Kaufman L (2001) Juvenile fish responses to variations in seafloor habitats: modeling the effects of fishing and implications for the design of marine protected areas. Conserv Biol 15:424-437

Lindholm J, Auster P, Valentine P (2004) Role of a large marine protected area for conserving landscape attributes of sand habitats on Georges Bank (northwest Atlantic). Mar Ecol Prog Ser 269:61-68

Lindholm J, Auster PJ, Knight A (2007) Site fidelity and movement of Atlantic cod (Gadus morhua) at deep boulder reefs in the western Gulf of Maine. Mar Ecol Prog Ser 342:239-247

Link JS (2002a) Ecological considerations in fisheries management: When does it matter? Fisheries 27:10-17

Link JS (2002b) Does food web theory work for marine ecosystems? Mar Ecol Prog Ser 230:1-9

Link JS (2007) Underappreciated species in ecology: ugly fish in the northwest Atlantic Ocean. Ecol Appl 17:2037-2060

Link JS, Almeida FP (2000) An overview and history of the food web dynamics program of the Northeast Fisheries Science Center, Woods Hole, Massachusetts. NOAA Tech Memo NMFS:NE-159

Link JS, Brodziak JKT, Edwards SF, Overholtz WJ and others (2002) Marine ecosystem assessment in a fisheries management context. Can J Fish Aquat Sci 59:1429-1440

Link JS, Stockhausen WT, Methratta ET (2005) Food web theory in marine ecosystems. In: Belgrano A, Scharler UM, Dunne J, Ulanowicz RE (eds) Aquatic food webs: an ecosystem approach. Oxford University Press, Oxford, p 98-113

Mangel M, Levin PS (2005) Regime, phase and paradigm shifts: making community ecology the basic science for

Editorial responsibility: Kenneth Sherman,

Narragansett, USA fisheries. Philos Trans R Soc Lond B Biol Sci 360:95-105

Methratta ET, Link JS (2006) Seasonal variation in groundfish habitat associations in the Gulf of Maine-Georges Bank region. Mar Ecol Prog Ser 326:245-256

Micheli F, Halpern BS (2005) Low functional redundancy in coastal marine assemblages. Ecol Lett 8:391-400

> Mueter FJ, Megrey BA (2006) Using multi-species surplus production models to estimate ecosystem-level maximum sustainable yields. Fish Res 81:189-201

Mumby PJ, Dahlgren CP, Harborne AR, Kappel CV and others (2006) Fishing, trophic cascades, and the process of grazing on coral reefs. Science 311:98-101

Murawski SA, Wigley SE, Fogarty MJ, Rago PJ, Mountain DG (2005) Effort distribution and catch patterns adjacent to temperate MPAs. ICES J Mar Sci 62:1150-1167

> Myers RA, Worm B (2003) Rapid worldwide depletion of predatory fish communities. Nature 423:280-283

> Naeem S (1998) Species redundancy and ecosystem reliability. Conserv Biol 12:39-45

NEFC (Northeast Fisheries Center) (1988) An evaluation of the bottom trawl survey program of the Northeast Fisheries Center. NOAA Tech Memo NMFS-NEC-52

> Newman MJH, Paredes GA, Sala E, Jackson JBC (2006) Structure of Caribbean coral reef communities across a large gradient of fish biomass. Ecol Lett 9:1216-1227

Overholtz WJ, Tyler AV (1985) Long-term responses of the demersal fish assemblages of Georges Bank. Fish Bull 83:507-520

> Pandolfi JM, Bradbury RH, Sala E, Hughes TP and others (2003) Global trajectories of the long-term decline of coral reef ecosystems. Science 301:955-959

$>$ Pershing AJ, Greene CH, Jossi JW, O'Brien L, Brodziak JKT, Bailey BA (2005) Interdecadal variability in the Gulf of Maine zooplankton community, with potential impacts on fish recruitment. ICES J Mar Sci 62:1511-1523

Randall JE (1967) Food habits of reef fishes of the West Indies. Stud Trop Oceanogr 5:665-847

> Ross ST (1986) Resource partitioning in fish assemblages: a review of field studies. Copeia 1986:352-368

Steele JH, Collie JS, Bisagni JJ, Gifford DJ and others (2007) Balancing end-to-end budgets of the Georges Bank ecosystem. Prog Oceanogr 74:423-448

Steneck RS, Vavrinec J, Leland AV (2004) Accelerating trophic-level dysfunction in kelp forest ecosystems of the western North Atlantic. Ecosystems 7:323-332

Walters C (1986) Adaptive management of renewable resources. Blackburn Press, Caldwell, NJ

Zar JH (1999) Biostatistical analysis, 4th edn. Prentice-Hall, Upper Saddle River, NJ

Submitted: August 29, 2008; Accepted: February 6, 2009

Proofs received from author(s): April 19, 2009 